\title{
PENGARUH KEPEMIMPINAN TRANSFORMASIONAL, INTEGRITAS, KOMPETENSI, DAN KOMITMEN ORGANISASI TERHADAP KINERJA KARYAWAN DI PT. GOLDEN RIAU JAYA PEKANBARU
}

\author{
Astri Ayu Purwati \& Indra Wijaya \\ Institut Bisnis dan Teknologi Pelita Indonesia \\ Jalan Jend. Ahmad Yani No. 78-88 Telp. (0761) 24418 Pekanbaru 28127 \\ Email: astri.ayu@lecturer.pelitaindonesia.ac.id,indrawijaya053@gmail.com
}

\begin{abstract}
ABSTRAK
Kinerja Karyawan diketahui sebagai faktor yang mempengaruhi berbagai aspek di PT.Golden Riau Jaya, adapun pada penelitian ini bertujuan untuk menguji dan menganalisis Pengaruh Kepemimpinan Transformasional, Integritas, Kompetensi dan Komitmen Organisasi terhadap Kinerja Karyawan PT. Golden Riau Jaya Pekanbaru. Pengumpulan data dilakukan melalui penyebaran kuesioner dan dilaksanakan pada 52 karyawan PT. Golden Riau Jaya yang juga merupakan populasi pada penelitian ini. Dalam penelitian ini teknik sampling yang digunakan teknik sampling jenuh merupakan teknik penentuan sampel bila semua anggota populasi digunakan sebagai sampel. Hasil penelitian ini menunjukkan bahwa variabel kepemimpinan transformasional tidak berpengaruh signifikan terhadap kinerja karyawan PT.Golden Riau Jaya Pekanbaru, variabel integritas berpengaruh signifikan terhadap kinerja karyawan PT.Golden Riau Jaya Pekanbaru, variabel Kompetensi berpengaruh signifikan terhadap kinerja karyawan PT.Golden Riau Jaya Pekanbaru, dan variabel komitmen organisasi berpengaruh tidak signifikan terhadap kinerja karyawan PT.Golden Riau Jaya Pekanbaru. Dengan demikian perusahaan PT.Golden Riau Jaya sebaiknya lebih memperhatikan variabel yang berpengaruh signifikan antara lain: integritas dan kompetensi.
\end{abstract}

Kata Kunci: Kepemimpinan Transformasional, Integritas, Kompetensi, Komitmen Organisasi, Kinerja Karyawan.

\begin{abstract}
Employee Performance is known as a factor that affects various aspects of PT. Golden Riau Jaya, while in this study aims to test and analyze the Effects of Transformational Leadership, Integrity, Competence and Organizational Commitment on Employee Performance at PT. Golden Riau Jaya Pekanbaru. Data collection was carried out through questionnaires and carried out on 52 employees of PT. Golden Riau Jaya which is also a population in this study. In this study the sampling technique used is saturation sampling technique is the technique of determining the sample if all members of the population are used as samples. The results of this study indicate that the transformational leadership variable does not significantly influence the performance of employees of PT. Golden Riau Jaya Pekanbaru, the integrity variable has a significant effect on the performance of employees of PT. Golden Riau Jaya Pekanbaru, Competence variables significantly influence the performance of employees of PT. Golden Riau Jaya Pekanbaru, and variable organizational commitment does not significantly influence the performance of employees of PT. Golden Riau Jaya Pekanbaru. Thus the company PT.Golden Riau Jaya should pay more attention to variables that have significant influence, including: integrity and competence.
\end{abstract}

Keywords: Transformational Leadership, Integrity, Competence, Organizational Commitment, Employee Performance

\section{Pendahuluan}

Diera globalisasi setiap organisasi atau perusahaan yang berbentuk swasta maupun pemerintah, tentunya memiliki tujuan baik itu jangka pendek maupun jangka panjang yang hendak dicapai melalui aktivitas yang dilakukannya. Agar tujuan yang telah ditetapkan tercapai maka diperlukan perencanaan dan pengelolaan sumber daya manusia sebaik-baiknya. Kegiatan-kegiatan pengorganisasian inilah yang melahirkan manajemen SDM. Manusia SDM merupakan unsur yang strategis dalam menentukan sehat tidaknya suatu organisasi. Pengembangan SDM yang terencana dan berkelanjutan merupakan kebutuhan yang mutlak terutama untuk masa depan organisasi. Manajemen Sumber Daya Manusia merupakan faktor yang sangat penting dalam 
sebuah organisasi dengan skala besar maupun kecil, sumber daya manusia dipandang sebagai unsur yang sangat menentukan dalam proses pengembangan organisasi karena pengembangan kualitas pelayanan akan terealisasi apabila ditunjang oleh sumber daya manusia yang berkualitas[1].

Setiap organisasi dituntut mampu berkompetisi agar dapat tetap bertahan dalam persaingan global. Strategi untuk selalu dapat berkompetisi adalah cara memperkuat kapasitas organisasi dan sumber daya manusia yang dimiliki. Akan tetapi masalah sumber daya manusia menjadi tantangan tersendiri bagi manajemen karena keberhasilan manajemen tergantung pada kualitas sumber daya manusia. Apabila sumber daya manusia dalam perusahaan dapat berjalan efektif maka perusahaan pun tetap bertahan efektif, dengan kata lain kelangsungan hidup perusahaan tergantung dari kinerja karyawan.

Kinerja dapat diasumsikan sebagah hasil dari suatu proses atau pekerjaan. Karena itu setiap karyawan dituntut untuk memiliki kompetensi yaitu kemampuan atau kecakapan melaksanakan tugas atau pekerjaan yang menjadi tanggung jawabnya atau yang dipercayakan. Setiap pelaksanaan tugas atau pekerjaan ada suatu kegiatan memproses atau mengubah input(masukan) menjadi suatu output(keluaran) yang bernilai tambah sebagai produk atau hasil kerja. Mangkunegara (2006) menyatakan, kinerja karyawan (prestasi kerja) adalah hasil kerja secara kualitas dan kuantitas yang dicapai oleh seseorang karyawan dalam melaksanakan tugasnya sesuai dengan tanggung jawab yang diberikan kepadanya[2], sedangkan Hariandja menyatakan, kinerja merupakan hasil kerja yang dihasilkan karyawam/pegawai atau perilaku nyata yang ditampilkan sesuai dengan perannya untuk mencapai tujuan organisasi[3]. Kinerja adalah hasil kerja yang disumbangkan seseorang karyawan yang berkaitan dengan tugas dan tanggungjawabnya kepada organisasi (perusahaan)yang didasari atas kecerdasan spiritual, intelegensia, emosional dan kecerdasan mengubah kendala menjadi peluang serta ketrampilan fisik yang diarahkan kepada pemanfaatan sumber daya yang disediakan oleh organisasi (perusahaan)[4]. Kinerja karyawan meliputi kualitas dan kuantitas output serta keandalan dalam bekerja. Karyawan dapat bekerja dengan baik bila memiliki kinerja yang tinggi sehingga dapat menghasilkan kerja yang baik pula. Dengan adanya kinerja yang tinggi yang dimiliki karyawan, diharapkan tujuan organisasi dapat tercapai. Sebaliknya, tujuan organisasi susah atau bahkan tidak dapat tercapai bila karyawannya bekerja tidak memiliki kinerja yang baik sehingga tidak dapat menghasilkan kerja yang baik pula.
PT. Golden Riau Jaya adalah perusahaan yang bergerak dibidang kelistrikan/ elektrikal yang beralamat di JL. Tuanku Tambusai, Pekanbaru yang berdiri tahun 2011 dimulai dengan sebuah toko bernama Pioneer" menjual peralatan lampu, kabel dan alat - alat listrik lainnya, dalam rangka memperluas jaringan pemasaran dan penjualan untuk memenuhi kebutuhan manufaktur dan kelautan industri yang menandai pertumbuhan yang stabil didirikanlah PT Golden Riau Jaya sebagai sebuah perusahaan khusus dalam memeasok peralatan listrik dan kabel. Meskipun usia yang relatif muda, PT. Golden Riau Jaya telah menjadi salah satu pemasok terbesar di Provinsi Riau khususnya kota Pekanbaru. Saat ini PT. Golden Riau Jaya memiliki 52 karyawan \& juga telah menjadi sub distributor visalux, scheneider, kabel metal indonesia dan pioline.

Berikut merupakan data pengukuran kinerja PT. Golden Riau Jaya berdasarkan data penjualan sales toko, dari tahun 2016 - 2018 .

Tabel 1. Data Target dan Capaian Penjualan PT. Golden Riau Jaya

\begin{tabular}{|c|l|l|l|}
\hline Tahun & Target & Penjualan & \% \\
\hline 2016 & $\begin{array}{l}6.500 .000 .00 \\
0\end{array}$ & $\begin{array}{l}\text { Rp.6.930.897. } \\
975\end{array}$ & $107 \%$ \\
\hline 2017 & $\begin{array}{l}6.700 .000 .00 \\
0\end{array}$ & $\begin{array}{l}\text { Rp.6.811.163. } \\
808\end{array}$ & $102 \%$ \\
\hline 2018 & $\begin{array}{l}7.000 .000 .00 \\
0\end{array}$ & $\begin{array}{l}\text { Rp. } 4.353 .671 . \\
962\end{array}$ & $62 \%$ \\
\hline 2019 & $\begin{array}{l}7.350 .000 .00 \\
0\end{array}$ & $\begin{array}{l}\text { Rp.4.297.895. } \\
298\end{array}$ & $58 \%$ \\
\hline
\end{tabular}

Sumber : Data Internal Bagian Penjualan PT. Golden Riau Jaya Tahun 2016 s/d 2018 (Diolah)

Dari data pengukuran kinerja cenderung penjualan dari tahun ke tahun mengalami penurunan sedangkan target penjualan yang harus dicapai setiap tahun meningkat, jumlah penjualan dalam rupiah pada tahun 2016 sebesar Rp. 6.930.897.975 sedangkan adapun target yang harus dicapai Rp.6.500.000.000 maka pencapaian tahun 2016 yaitu 107\%, jumlah penjualan tahun 2017 terdapat penurunan sebesar Rp.6.811.163.808 sedangkan adapun target yang harus dicapai Rp.6.700.000.000 maka pencapaian tahun 2017 yaitu $102 \%$, jumlah penjualan tahun 2018 terdapat penurunan yang signifikan sebesar Rp.4.353.671.962 sedangkan adapun target yang harus dicapai Rp.7.000.000.000 maka pencapaian tahun 2018 yaitu $62 \%$, jumlah penjualan pada tahun 2019 terdapat penurunan sebesar Rp.4.297.895.298 sedangkan adapun target yang harus dicapai Rp.7.000.000.000 maka pencapaian tahun 2019 yaitu $58 \%$. Dengan demikian penjualan dari tahun ke tahun mengindikasikan kategori 
kinerja organisasi semakin berkurang ini merupakan dampak berkurangnya kinerja organisasi yang mempengaruhi kurangnya kinerja karyawan. Karena target penjualan perusahaan diturunkan kepada seluruh karyawan sebagai tugas dan tanggung jawab. Untuk itu perlu adanya suatu perhatian dari PT. Golden Riau Jaya untuk memperhatikan dan memperbaiki strategi - strategi yang dapat meningkatkan kinerja karyawan.

Dalam suatu organisasi atau perusahaan kepemimpinan merupakan salah satu faktor penting. Kepemimpinan itu sendiri merupakan suatu pola perilaku yang ditampilkan sebagai pimpinan ketika mencoba mempengaruhi perilaku orang lain. Oleh karena itu perilaku yang diperlihatkan oleh bawahan pada dasarnya adalah respon bawahan terhadap gaya kepemimpinan yang dilakukan pada mereka. Gaya kepemimpinan ada beberapa jenis, salah satunya yaitu kepemimpinan transformasional. Kepemimpinan transformasional adalah pemimpin yang kharismatik dan mempunyai peran sentral serta strategi dalam membawa organisasi mencapai tujuannya. Pemimpin transformasional juga harus mempunyai kemampuan untuk menyamakan visi masa depan dengan bawahannya, serta mempertinggi kebutuhan bawahan pada tingkat yang lebih tinggi dari pada apa yang mereka butuhkan. Adanya penurunan kinerja karyawan tersebut dikarenakan peran kepemimpinan dalam hal ini gaya kepemimpinan yang transformasional yang masih kurang baik. Oleh karena itu, peran seorang pimpinan yang mempuyai gaya kepemimpinan transformasional di PT.Golden Riau Jaya diperlukan agar dapat memberikan pengarahan dan sebagai teladan sehingga akan berpengaruh terhadap kinerja karyawan di PT.Golden Riau Jaya.

Kepemimpinan transformasional merupakan pemimpin yang menginspirasi para pengikut untuk melampaui kepentingan pribadi mereka dan yang mampu membawa dampak mendalam dan luar biasa pada para pengikut. Menurut Safaria dan Saputra kepemimpinan transformasional dicirikan sebagai emimpin yang berfokus pada pencapaian perubahan nilai-nilai, kepercayaan, sikap, perilaku, emosional dan kebutuhan bawahan menuju perubahan yang lebih baik di masa depan[5]. Pemimpin transformasional merupakan seorang agen perubahan yang berusaha keras melakukan transformasi ulang organisasi secara menyeluruh sehingga organisasi bisa mencapai kinerja yang lebih maksimal di masa depan. Mondiani yang mengemukakan kepemimpinan transformasional merupakan kemampuan untuk memberikaninspirasi dan memotivasi para pengikutnya untuk mencapai hasil-hasil yang lebih besar daripada yang direncanakan secara orisinil[6].
Berdasarkan penelitian yang dilakukan oleh [7-12] ditemukan bahwa kepemimpinan transformasional berpengaruh positif signifikan terhadap kinerja karyawan.

Selain faktor kepemimpinan transformasional, terdapat faktor lain yaitu integritas. Integritas sering dipahami dalam konteks perilaku, dan perilaku integritas pada umumnya dipahami dalam kaitannya dengan etika dan moral. Integritas juga mewajibkan individu agar taat terhadap standar teknis dan etika yang dimiliki organisasi. Integritas bukan hanya masalah kejujuran, masalah etis dan moral,bahwa orang tidak berbohong atau tidak melakukan hal-hal tidak bermoral. Integrity berkaitan juga dengan kinerja, suatu pencapaian hasil baik yang dicapai dengan selalu menjunjung tinggi kejujuran dan nilai-nilai moral lainnya. Kata integrity berasal dari akar kata "integrated", yang berarti berbagai bagian dari karakter dan keterampilan berperan aktif dalam diri kita, yang tampak dari keputusandan tindakan-tindakan kita Atosokhi,[13] . Seseorang karyawan yang integritas kurang baik dalam dirinya seperti harus bersifat jujur, berani, berdaya juang, membangun hubungan baik, pandai mengorganisasikan diri sendiri, teratur, dan terencana dengan baik, maka akan mengakibatkan penurunan kinerja karyawan tersebut. Karyawan pada PT. Golden Riau Jaya karyawan tersebut berdaya juang rendah, rendahnya keberanian dalam melakukan hal - hal yang baru akan, sehingga hal ini berdampak terhadap kinerja karyawan tersebut.

Berdasarkan penelitian terdahulu oleh Salwa \&Away [14] hasil analisis menunjukkan berdasarkan hasil pengujian hipotesis membuktikan Integritas tidak berpengaruh signifikan terhadap kinerja karyawan. Berbeda dengan penelitian terdahulu yaitu hasil analisis menunjukkan intergritas berpengaruh signifikan terhadap kinerja karyawan[15-17].

Adapun faktor lainnya yaitu kompetensi merupakan karakteristik dasar dari seseorang yang memungkinkan mereka mengeluarkan kinerja superior dalam pekerjaannya[18]. Berdasarkan uraian tersebut maka makna kompetensi mengandung bagian kepribadian yang mendalam dan melekat pada seseorang dengan perilaku yang dapat diprediksi pada berbagai keadaan dan tugas pekerjaan. Prediksi siapa yang berkinerja baik dan kurang baik dapat diukur dari kriteria atau standar yang digunakan. Analisis kompetensi disusun sebagian besar untuk pengembangan karier, tetapi penentuan tingkat kompetensi dibutuhkan untuk mengetahui efektivitas tingkat kinerja yang diharapkan. Level kompetensi secara berurutan adalah sebagai berikut: Skill, Knowledge, Self Concept, Self Image, Trait dan Motive. Kompetensi Skill dan Knowledge cenderung lebih nyata 
(visible) dan relatif berada di permukaan (ujung) sebagai karakteristik yang dimiliki manusia. Pada PT.Golden Riau Jaya tersebut adanya tingkat kompetensi yang kurang baik antar karyawan, dalam hal ini ditandai adanya persaingan yang tidak sehat dalam memenuhi target individu dari karyawan tersebut. Adanya kompetensi yang kurang baik tersebut memiliki dampak terhadap target penjualan yang hendak dicapai perusahaan, karena dengan kompetensi antar karyawan yang kurang baik tersebut akan mempengaruhi target penjualan yang hendak dicapai perusahaan tersebut karena penjualan perusahaan setiap tahun mengindikasikan kinerja karyawan, sebab target penjualan perusahaan diturunkan oleh perusahaan kepada seluruh karyawan sebagai tugas dan tanggung jawab bersama

Penelitian terdahulu oleh Dhermawan,et al[18], hasil analisis menunjukkan kompetensi tidak berpengaruh signifikan terhadap kinerja, yang artinya kurang berpengaruhnya kompetensi terhadap kinerja pegawai berarti meskipun pegawai memiliki kompetensi yang baik, hal tersebut tidak berpengaruh signifikan atau memberikan pengaruh yang kecil terhadap peningkatan kinerja pegawai.. Sedangkan penelitian terdahulu yang dilakukan oleh [19], hasil analisis menunjukkan kompetensi berpengaruh positif dan signifikan terhadap kinerja karyawan. Hasil penelitian ini menunjukkan bahwa kompetensi yang dimiliki semakin tinggi akan membuat kinerja karyawan juga semakin tinggi.

Terakhir, selain kepemimpinan transformasional, integritas dan kompetensi, terdapat satu faktor lainnya yaitu komitmen organisasi merupakan suatu kondisi yang dirasakan oleh karyawan yang dapat menimbulkan perilaku positif yang kuat terhadap organisasi kerja yang dimilikinya[20,21] Berpendapat bahwa komitmen organisasional merupakan tingkat kekerapan identifikasi dan keterikatan individu terhadap organisasi yang dimasukinya, dimana karakteristik komitmen organisasional antara lain adalah: loyalitas seseorang terhadap organisasi, kemauan untuk mempergunakan usaha atas nama organisasi, kesesuaian antara tujuan seseorang dengan tujuan organisasi, dan keinginan untuk menjadi anggota organisasi. Komitmen organisasi secara umum dipahami sebagai ikatan kejiwaan individu terhadap organisasi termasuk keterlibatan kerja, kesetiaan dan perasaan percaya pada nilai-nilai organisasi [22]. Pada perusahaan PT.Golden Riau Jaya Pekanbaru, kurangnya kerjasama antar karyawan dan perusahaan, dalam hal ini timbulnya rasa tidak puas sehingga karyawan tersebut tidak loyal terhadap perusahaan serta setelah bekerja, adanya ketidak nyamanan dan kurangnya keinginan untuk menjadi anggota organisasi. Dengan demikian rasa loyalitas dan keterikatan karyawan kepada perusahaan tidak menghasilkan komitmen karyawan yang baik sehingga karyawan tentunya tidak bekerja dengan baik dan tentunya hal itu berdampak terhadap kinerja karyawan tersebut.

Penelitian terdahulu oleh Lovina Hendriani dan Marnis [23] Menunjukkan pengaruh secara langsung Komitmen Organisasi terhadap Kinerja merupakan pengaruh positif yang signifikan. Sedangkan penelitian terdahulu oleh [24] hasil analisis menunjukkan komitmen organisasi berpengaruh negatif terhadap kinerja karyawan

\section{Metode Penelitian}

\section{Populasi dan Sampel Populasi}

Dalam penelitian ini populasi adalah seluruh karyawan yang bekerja di PT.Golden Riau Jaya yang berjumlah 52 orang.

\section{Sampel}

Pengertian sampel menurut Sugiyono, (2012)adalah bagian dari jumlah dan karakteristik yang dimiliki oleh populasi tersebut sampel yang diambil dari populasi tersebut harus betul-betul representative(mewakili). Dalam penelitian ini pengambilan sampel dapat diambil dalam teknik sampling jenuh. Menurut (Sugiyono, 2012)teknik sampling jenuh merupakan teknik penentuan sampel bila semua anggota populasi digunakan sebagai sampel. Jumlah populasi yang ada pada PT.Golden Riau Jaya yaitu sebanyak 52 orang responden dan keseluruhan populasi tersebut dijadikan sampel dalam penelitian ini, Dengan demikian penggunaan seluruh populasi tanpa harus menarik sampel penelitian sebagai unit observasi disebut sebagai teknik sensus.

\section{Metode Analisis Data Uji Validitas}

Menurut Arikunto(2013) validitas adalah suatu ukuran yang menunjukkan tingkat - tingkat kevalidan atau keahlian sesuatu instrumen. Suatu instrumen yang valid mempuyai validitas tinggi. Sebaliknya instrumen yang kurang valid berarti memiliki validitas rendah, uji validitas dilakukan untuk mengukur sah atau tidaknya indikator atau kuesioner/instrumen dari masing - masing variabel. Suatu instrumen dikatakan valid apabila instrumen tersebut mengukur apa yang seharusnya diukur. Apabila nilai validitas tiap butir pernyataannya $>$ 0.30 , maka butir - butir pernyataan dikatakan valid. Uji validitas dilakukan untuk mengukur sah atau tidaknya indikator atau kuesioner/instrumen dari masing - masing variabel. Suatu instrumen dikatakan valid apabila instrumen mengukur apa yang seharusnya diukur. Apabila nilai validitas tiap butir pernyataannya $>0.30$, maka butir - butir pernyataan dikatakan valid. 


\section{Uji Realibilitas}

Menurut Arikunto, (2013) realibilitas menunjuk pada satu pengertian bahwa sesuatu instrumen cukup dapat dipercaya untuk digunakan sebagai alat pengumpul data karena instrumen tersebut sudah baik. Instrumen yang sudah baik tidak akan bersifat tendesius mengarahkan responden untuk memilih jawaban - jawaban tertentu. Instrumen yang sudah dipercaya, yang reliabel akan menghasilkan data yang dapat dipercaya juga.

Apabila jawaban yang diberikan konsisten, maka dikatakan instrumen penelitian telah dapat diandalkan (reliable). Dalam penelitian ini pengujian realibilitas angket hanya dilakukan satu kali (one shot), dengan menggunakan fitur cronbach alpha pada SPSS for windows. Apabila bilai cronbach alpha $>0.60$, maka dikatakan angket telah reliable.

\section{Uji Model (F)}

Menurut Ghozali (2013) pengujian ini bertujuan untuk mengetahui pengaruh variabel independen secara bersama-sama terhadap variabel dependen dengan melihat nilai signifikansi F.

Langkah - langkah pengujian simultan sebagai berikut Ghozali(2013) :

Rumusan Hipotesis :

$\mathrm{H}_{0}: \mathrm{b}_{1}=\mathrm{b}_{2}=\mathrm{b}_{3}=\mathrm{b}_{4}=0$, berarti tidak ada pengaruh variabel independen secara simultan terhadap variabel dependen.

$\mathrm{H}_{\mathrm{A}}: \mathrm{b}_{1} \neq \mathrm{b}_{2} \neq \mathrm{b}_{3} \neq \mathrm{b}_{4} \neq 0$, berarti ada pengaruh variabel independen secara simultan terhadap variabel dependen

Tingkat signifikan yaitu $\alpha=5 \%$ dan Kriteria Keputusan, Jika $\mathrm{F}$ hitung $>\mathrm{F}$ tabel atau nilai signifikan $<0.05$, maka $\mathrm{H}_{0}$ ditolak dan $\mathrm{H}_{1}$ diterima, berarti variabel independen secara bersama-sama mempuyai pengaruh terhadap variabel dependen atau jika $\mathrm{F}$ hitung $<\mathrm{F}$ tabel atau nilai signifikan $>$ 0.05 , maka $\mathrm{H}_{0}$ diterima dan $\mathrm{H}_{1}$ ditolak, berarti variabel independen secara bersama- sama tidak mempuyai pengaruh terhadap variabel dependen.

\section{Uji Koefisien Determinasi $\left(\mathbf{R}^{\mathbf{2}}\right)$}

Menurut Ghozali(2013) koefisien determinasi $\left(\mathrm{R}^{2}\right)$ merupakan alat untuk mengukur seberapa jauh kemampuan model dalam menerangkan variasi variabel dependen. Dalam bahasa sehari- hari adalah kemampuan variabel bebas untuk berkontribusi terhadap variabel tetapnya dalam satuan persentase.

Nilai koefisien ini antara 0 dan 1 , jika hasil lebih mendekati angka 0 berarti kemampuan variabel - variabel independen dalam menjelaskan variasi variabel amat terbatas. Tapi jika hasil mendekati angka 1 berarti variabel - variabel independen memberikan hampir semua informasi yang dibutuhkan untuk memprediksi variabel variabel dependen. Untuk analisisnya dengan menggunakan output SPSS dapat dilihat pada tabel "Model Summary".

\section{Uji Parsial (uji -t)}

Menurut Ghozali(2013) pengujian ini bertujuan untuk mengetahui apakah dalam model regresi linear, variabel independen secara parsial mempuyai pengaruh terhadap variabel dependen. Pengujian ini dilakukan dengan membandingkan nilai $\mathrm{t}$ hitung dengan $\mathrm{t}$ tabel masing-masing variabel.

Langkah-langkah pengujian parsial sebagai berikut (Ghozali, 2013) :

Rumusan Hipotesis

$\mathrm{H}_{0}: \mathrm{b}_{1}=0$, berarti tidak ada pengaruh variabel independen (Kepemimpinan transformasional, integritas, kompetensi dan komitmen organisasi) secara parsial terhadap variabel dependen (Kinerja karyawan)

$\mathrm{H}_{1}: \mathrm{b}_{1} \neq 0$, berarti ada pengaruh variabel kepemimpinan transformasional secara parsial terhadap variabel kinerja karyawan.

$\mathrm{H}_{2}: b_{1} \neq 0$, berarti ada pengaruh variabel integritas secara parsial terhadap variabel kinerja karyawan.

$\mathrm{H}_{3}: \mathrm{b}_{1} \neq 0$, berarti ada pengaruh variabel kompetensi terhadap variabel kinerja karyawan.

$\mathrm{H}_{4}: \mathrm{b}_{1} \neq 0$, berarti ada pengaruh variabel komitmen organisasi secara parsial terhadap variabel kinerja karyawan.

Tingkat signifikan yaitu $\alpha=5 \%$ dan kriteria keputusan, jika $\mathrm{t}$ hitung $>\mathrm{t}$ tabel atau nilai signifikan $<0.05$, maka $\mathrm{H}_{0}$ ditolak dan $\mathrm{H}_{1}$ diterima, berarti variabel independen secara bersama-sama mempuyai pengaruh terhadap variabel dependen, atau jika $\mathrm{t}$ hitung $<\mathrm{t}$ tabel atau nilai signifikan $>$ 0.05 , maka $\mathrm{H}_{0}$ diterima dan $\mathrm{H}_{1}$ ditolak, berarti variabel independen secara bersama-sama tidak mempuyai pengaruh terhadap variabel dependen.

\section{Hasil dan Pembahasan}

\section{Uji Model (F)}

Untuk menguji hipotesis penelitian yang menyatakan bahwa kepemimpinan transformasional, integritas, kompetensi dan komitmen organisasi secara simultan memiliki pengaruh yang signifikan terhadap kinerja karyawan, maka perlu dilakukan pengujian secara simultan atau uji f.

Model hipotesis yang diajukan antara lain : 1 . $\mathrm{H} 0: \beta 1=\beta 2=\beta 3=0$, artinya kepemimpinan transformasional, integritas, kompetensi dan komitmen organisasi secara simultan tidak mempengaruhi kinerja karyawan, $2 . \mathrm{H} 1$ : minimal 
satu $\beta \neq 0$, artinya kepemimpinan transformasional, integritas, kompetensi dan komitmen organisasi secara simultan berpengaruh terhadap kinerja karyawan.

Kinerja untuk pengujian hipotesis secara simultan ini adalah jika Fhitung pada $\alpha=5 \%$, maka $\mathrm{H} 0$ diterima dan $\mathrm{H} 1$ ditolak, sebaliknya jika $\mathrm{F}_{\text {hitung }}>$ Ftabel pada $\alpha=5 \%$, maka $\mathrm{H} 0$ ditolak dan $\mathrm{H} 1$ diterima

Hasil pengujian secara simultan dapat dilihat pada tabel 4 dibawah ini :

Tabel 4. Uji Model (F)

\begin{tabular}{|c|c|c|c|c|}
\hline Variabel & $\begin{array}{c}\text { F } \\
\text { hitung }\end{array}$ & $\begin{array}{c}\text { F } \\
\text { tabel }\end{array}$ & Sig. & Keterangan \\
\hline $\begin{array}{c}\mathrm{X}_{1}, \mathrm{X}_{2}, \mathrm{X}_{3}, \mathrm{X}_{4} \\
\text { terhadap } \mathrm{Y}\end{array}$ & 32,604 & 2,57 & 0,000 & $\begin{array}{c}\text { Berpengaruh } \\
\text { signifikan }\end{array}$ \\
\hline
\end{tabular}

*Ftabel di hitung dengan rumus $\mathrm{df}=(\mathrm{k}-1)(\mathrm{n}-\mathrm{k})=>\mathrm{df} 1=(5-$ 1) $=4 \mathrm{df} 2=(52-5)=47$ (merujuk tabel $\mathrm{f})$

Sumber : Hasil Penelitian, 2019 (Data Olahan)

Dari hasil pengujian secara simultan diperoleh hasil $F_{\text {hitung }}$ adalah 32,604 sedangkan hasil $F_{\text {tabel }}$ adalah 2,57. Hal ini berarti $F_{\text {hitung }}>F_{\text {tabel }}$ dan nilai signifikan $0,000<$ alpha 0,05 . Jadi dengan demikian maka H0 ditolak dan $\mathrm{H} 1$ diterima. Artinya kepemimpinan transformasional, integritas, kompetensi dan komitmen organisasi secara simultan berpengaruh dan signifikan terhadap kinerja karyawan.

\section{Koefisien Determinasi $\left(\mathbf{R}^{2}\right)$}

Nilai koefisien determinasi $\left(\mathrm{R}^{2}\right)$ digunakan untuk menjelaskan proporsi variasi dalam variabel terikat yang dijelaskan oleh variabel bebas secara besama-sama.

Tabel 5. Koefisien Determinasi $\left(\mathbf{R}^{2}\right)$ Model Summary ${ }^{b}$

\begin{tabular}{|c|c|c|c|}
\hline Model & R & R Square & $\begin{array}{c}\text { Adjusted } \\
\text { R Square }\end{array}$ \\
\hline 1 & $0.857^{\mathrm{a}}$ & 0.735 & 0.713 \\
\hline
\end{tabular}

Sumber : Hasil Penelitian, 2019 (Data Olahan)

Dari tabel 21 menunjukkan nilai adjusted $\mathrm{R}^{2}$ sebesar 0,713. Hal ini berarti bahwa variabel kinerja karyawan dijelaskan oleh variabel kepemimpinan transformasional, integritas, kompetensi dan komitmen organisasi sebesar 71,3\%, sedangkan sebesar $28,7 \%$ dijelaskan oleh variabel lain yang tidak diteliti dalam model. Nilai 71,3\% menyatakan bahwa model penelitian dapat dikatakan baik karena mendekati nilai 1,00 atau $100 \%$.

Uji Hipotesis

\section{Uji Parsial (uji-t)}

Pengujian hipotesis secara parsial (uji t) berguna untuk menguji pengaruh secara parsial dari variabel $\mathrm{X}$ terhadap variabel $\mathrm{Y}$. Dalam penelitian ini akan diuji pengaruh secara parsial dari variabel $\mathrm{X}$, yaitu kepemimpinan transformasional, integritas, kompetensi dan komitmen organisasi terhadap variabel $\mathrm{Y}$ yaitu kinerja karyawan. Hasil pengujian secara parsial dalam penelitian ini dapat dilihat pada tabel 7 berikut ini :

Tabel 7. Uji Signifikansi Secara Parsial (uji t)

\begin{tabular}{|c|c|c|c|c|}
\hline Model & T Hitung & $\begin{array}{c}\text { T } \\
\text { Tabel }\end{array}$ & Sig & Keterangan \\
\hline $\begin{array}{c}\text { X1 (Kepemimpinan } \\
\text { Transformasional) }\end{array}$ & -1.809 & 2.013 & 0.077 & $\begin{array}{c}\text { Tidak berpengaruh dan tidak } \\
\text { signifikan }\end{array}$ \\
\hline X2 (Integritas) & 8.16 & 2.013 & 0.000 & Berpengaruh Signifikan \\
\hline X3 (Kompetensi) & 5.884 & 2.013 & 0.000 & Berpengaruh Signifikan \\
\hline X4 ( Komitmen Organisasi) & 1.381 & 2.013 & 0.174 & $\begin{array}{c}\text { Tidak Berpengaruh dan tidak } \\
\text { signifikan }\end{array}$ \\
\hline
\end{tabular}

*t tabel di hitung dengan rumus $\mathrm{df}=\mathrm{n}-\mathrm{k}-1=>52-5-1=46$ (merujuk tabel $\mathrm{t}$ )

Sumber :Hasil Penelitian, 2019 (Data Olahan)

Dari tabel 7 diatas, hasil pengujian secara parsial dapat dijelaskan sebagai berikut: 1.pengaruh kepemimpinan transformasional terhadap kinerja karyawan, hipotesis yang diajukan untuk pengaruh kepemimpinan transformasional terhadap kinerja karyawan adalah : $\mathrm{H} 0: \beta 1=0$ dan $\mathrm{H} 0: \beta 1 \neq 0$, hasil pengujian menunjukkan bahwa nilai thitung untuk variabel kepemimpinan transformasional $-1,809$ lebih kecil dari $t_{\text {tabel }} 2,013$ dan nilai signifikan 0,077 lebih besar dari alpha 0,05 . Hal ini berarti bahwa kepemimpinan transformasional tidak berpengaruh dan tidak signifikan terhadap kinerja karyawan, 2. pengaruh integritas terhadap kinerja karyawan. Hipotesis yang diajukan untuk pengaruh integritas terhadap kinerja karyawan adalah : $\mathrm{H} 0: \beta 2=0$ dan
H0 : $\beta 2 \neq 0$, hasil pengujian menunjukkan bahwa nilai thitung untuk variabel integritas 8,160 lebih besar dari tabel 2,013 dan nilai signifikan 0,000 lebih kecil dari 0,05 . Hal ini berarti bahwa integritas berpengaruh signifikan terhadap kinerja karyawan, 3.pengaruh kompetensi terhadap kinerja karyawan, hipotesis yang diajukan untuk pengaruh kompetensi terhadap kinerja karyawan adalah : $\mathrm{H} 0: \beta 3=0$ dan $\mathrm{H} 0: \beta 3 \neq 0$. Hasil pengujian menunjukkan bahwa nilai thitung untuk variabel kompetensi 5,884 lebih besar dari $t_{\text {tabel }} 2,013$ dan nilai signifikan 0,000 lebih kecil dari 0,05 . Hal ini berarti bahwa kompetensi berpengaruh signifikan terhadap kinerja karyawan, 4.pengaruh komitmen organisasi terhadap kinerja karyawan, hipotesis yang diajukan untuk pengaruh 
komitmen organisasi terhadap kinerja karyawan adalah : $\mathrm{H} 0: \beta 4=0$ dan $\mathrm{H} 0: \beta 4 \neq 0$, hasil pengujian menunjukkan bahwa nilai thitung untuk variabel komitmen organisasi 1,381 lebih kecil dari tabel 2,013 dan nilai signifikan 0,174 lebih besar dari 0,05 . Hal ini berarti bahwa komitmen organisasi tidak berpengaruh dan tidak signifikan terhadap kinerja karyawan.

\section{Pembahasan}

\section{Pengaruh Kepemimpinan Transformasional} Terhadap Kinerja Karyawan

Pemimpin transformasional adalah seseorang pemimpin yang menguasai situasi dengan menyampaikan visi yang jelas tentang tujuan kelompok, bergairah dalam pekerjaan dan kemampuan untuk membuat anggota kelompok merasa diisi ulang dan berenergi. Berdasarkan hasil analisis secara deskriptif menunjukkan bahwa kepemimpinan transformasional merupakan variabel yang dinilai baik bagi responden. Sedangkan dari hasil uji (t) dapat dilihat bahwa kepemimpinan transformasional terhadap kinerja karyawan tidak berpengaruh signifikan, adapun hal ini dipengaruhi, masih ada beberapa responden yang memberikan respon sangat tidak baik dan tidak baik terhadap beberapa indikator kepemimpinan transformasional yaitu karisma, inspirasi dan perilaku/perhatian.

Hal ini berarti secara parsial dapat dinyatakan variabel kepemimpinan transformasional tidak berpengaruh dan tidak signifikan secara nyata terhadap kinerja karyawan. Dan karena variabel kepemimpinan transformasional memiliki koefisiensi regresi yang negatif, hal ini berarti bahwa kepemimpinan transformasional memiliki pengaruh yang negatif terhadap kinerja karyawan.

Hal ini tidak sejalan dengan penelitian terdahulu yang dilakukan oleh Rahyuda, et al (2017) dengan objek (studi pada PT. Sasjam Riri Kabupaten Gianyar) yang menyatakan bahwa kepemimpinan transformasional berpengaruh signifikan terhadap kinerja karyawan.

\section{Pengaruh Integritas Terhadap Kinerja \\ Karyawan}

Integritas adalah suatu konsep berkaitan dengan konsistensi dalam tindakan-tindakan, nilainilai, metode-metode, ukuran-ukuran, prinsipprinsip, ekspektasi-ekspektasi dan berbagai hal yang dihasilkan. Adapun seseorang yang berintegritas yaitu orang-orang yang mengatakan kebenaran, dan orang-orang itu memegang katakata mereka. Mereka bertanggung-jawab atas tindakan-tindakan mereka di masa lalu, mengakui kesalahan mereka dan mengoreksinya. Mereka mengetahui hukum yang berlaku dalam negara mereka, industri mereka dan perusahaan mereka - baik yang tersurat maupun yang tersirat - dan mentaatinya. Sementara itu berdasarkan hasil analisis secara deskriptif menunjukkan bahwa integritas merupakan variabel yang dinilai baik bagi responden. Hal ini dilihat berdasarkan pernyataan yang di tujukan kepada responden. Sedangkan dari pengujian secara parsial (uji t) terhadap variabel integritas yang menunjukkan integritas berpengaruh signifikan terhadap kinerja karyawan

Hal ini berarti secara simultan dapat dinyatakan variabel integritas berpengaruh signifikan secara nyata terhadap kinerja karyawan. Dan karena variabel integritas memiliki koefisien yang positif, hal ini berarti bahwa integritas memiliki pengaruh positif terhadap kinerja karyawan.

Hal ini sejalan dengan penelitian terdahulu yang telah dilakukan oleh Hendrawan \& Budiartha, (2018) dengan objek penelitian (studi pada Inspektorat kota Denpasar) yang menyatakan bahwa integritas berpengaruh dan signifikan terhadap kinerja karyawan.

\section{Pengaruh Kompetensi Terhadap Kinerja Karyawan}

Kompentesi adalah suatu keterampilan, pengetahuan, sikap dasar, dan nilai yang terdapat dalam diri seseorang yang tercermin dari kemampuan berpikir dan bertindak secara konsisten. Kompetensi tidak hanya tentang pengetahuan atau kemampuan seseorang, namun kemauan melakukan apa yang diketahui sehingga menghasilkan manfaat. Berdasarkan hasil analisis secara deskriptif menunjukkan bahwa kompetensi merupakan variabel yang dinilai baik bagi responden. Serta dari hasil uji (t) dapat dilihat bahwa kompetensi terhadap kinerja karyawan berpengaruh signifikan. Hal ini sejalan dengan hasil analisis deskriptif, hasil analisis regresi dan pengujian secara parsial (uji t) terhadap variabel kompetensi yang menunjukkan kompetensi berpengaruh signifikan terhadap kinerja karyawan.

Hal ini berarti secara parsial dapat dinyatakan variabel kompetensi berpengaruh signifikan secara nyata terhadap kinerja karyawan. Dan karena variabel kompetensi memiliki koefisien yang positif, hal ini berarti bahwa kompetensi memiliki pengaruh positif terhadap kinerja karyawan.

Adapun penelitian terdahulu yang mendukung pengujian tersebut menyatakan bahwa kompetensi berpengaruh signifikan terhadap kinerja karyawan menurut Ataunur \& Ariyanto (2015) dengan objek (studi pada PT.Adaro Energi TBK).

\section{Pengaruh Komitmen Organisasi Terhadap Kinerja Karyawan}

Komitmen organisasi adalah sikap atau bentuk perilaku seseorang terhadap organisasi 
dalam bentuk loyalitas dan pencapaian visi, misi, nilai dan tujuan organisasi. Seseorang dikatakan memiliki komitmen yang tinggi terhadap organisasi, dapat dikenali dengan ciri-ciri antara lain kepercayaan dan penerimaan yang kuat terhadap tujuan dan nilai-nilai organisasi, kemauan yang kuat untuk bekerja demi organisasi dan keinginan yang kuat untuk tetap menjadi anggota organisasi. Berdasarkan hasil analisis secara deskriptif menunjukkan bahwa komitmen organisasi merupakan variabel yang dinilai baik bagi responden. Sedangkan dari hasil uji (t) dapat dilihat bahwa komitmen organisasi terhadap kinerja karyawan tidak berpengaruh signifikan, Hal ini tidak sejalan dengan hasil analisis deskriptif yang menunjukkan komitmen organisasi berpengaruh terhadap kinerja karyawan, tetapi hal ini sejalan dengan hasil analisis regresi dan pengujian secara parsial (uji t) terhadap variabel komitmen organisasi yang berpengaruh tidak signifikan.

Hal ini berarti secara parsial dapat dinyatakan variabel komitmen organisasi tidak berpengaruh dan tidak signifikan secara nyata terhadap kinerja karyawan. Dan karena variabel komitmen organisasi memiliki koefisien yang positif, hal ini berarti bahwa komitmen organisasi memiliki pengaruh positif terhadap kinerja karyawan.

Adapun penelitian terdahulu yang mendukung pernyataan tersebut menyatakan bahwa komitmen organisasi tidak bepengaruh terhadap kinerja karyawan menurut Handayani, (2008) dengan objek (studi pada PT. HM Sampoerna TBK di Surabaya).

\section{PENUTUP}

\section{Kesimpulan}

Penelitian ini bertujuan untuk mengetahui pengaruh kepemimpinan transformasional, integritas, kompetensi dan komitmen organisasi terhadap kinerja karyawan PT. Golden Riau Jaya Pekanbaru. Adapun Kesimpulan yang dapat ditarik dari hasil penelitian yang telah dilakukan antara lain : 1.kepemimpinan transformasional tidak berpengaruh signifikan terhadap kinerja karyawan PT.Golden Riau Jaya Pekanbaru. Dalam Penelitian ini variabel kepemimpinan transformasional memiliki pengaruh yang negatif yang berarti apabila kepemimpinan transformasional baik tidak akan meningkatkan kinerja karyawan. 2.integritas berpengaruh signifikan terhadap kinerja karyawan PT.Golden Riau Jaya Pekanbaru. Dalam Penelitian ini variabel integritas memiliki pengaruh yang positif yang berarti apabila integritas baik akan meningkatkan kinerja karyawan. 3.Kompetensi berpengaruh signifikan terhadap kinerja karyawan PT.Golden Riau Jaya Pekanbaru. Dalam Penelitian ini variabel kompetensi memiliki pengaruh yang positif yang berarti apabila kompetensi baik kana meningkatkan kinerja karyawan. 4.komimen organisasi bepengaruh tidak signifikan terhadap kinerja karyawan PT.Golden Riau Jaya Pekanbaru. Dalam penelitian ini variabel komitmen organisasi memiliki pengaruh yang positif namun tidak memberikan pengaruh signifikan yang berarti apabila komitmen organisasi baik tidak akan meningkatkan kinerja karyawan secara signifikan.

Berdasarkan kesimpulan yang diperoleh dalam penelitian ini, maka diajukan saran - saran sebagai pelengkap terhadap hasil penelitian tersebut sebagai berikut : 1.Bagi Praktisi, Adapun beberapa aspek yang dianggap perlu dan penting untuk diperhatikan oleh pihak perusahaan maupun bagi karyawan itu sendiri yaitu: a.integritas, integritas yang dikatakan baik itu harus memiliki nilai-nilai seperti kejujuran, keterbukaan, tanggung jawab, ketekunan, kerajinan, keberanian, ke-terusterangan, kepercayaan, kesetiaan, kearifan dan profesionalisme, sebab Di dalam sebuah perusahaan, integritas merupakan awal dari sebuah janji dan komitmen dalam membangun bisnis dan pelayanan kepada stakeholder. Bila sebuah perusahaan gagal menegakkan integritas sebagai pilar terpenting di perusahaannya, maka janganlah berharap semua pimpinan dan karyawan akan mampu menjalankan perusahaan secara profesional. oleh karenanya, penegakkan integritas sifatnya adalah mutlak dalam semua operasional perusahaan b.kompetensi, kompetensi membantu perusahaan untuk mendeskripsikan bagaimana kinerja seseorang. Hal ini tentu saja berkaitan dengan pengetahuan, keahlian, dan kemampuan kerja seseorang atas bidang kerja tertentu. Kompetensi merepresentasikan dimensi kerja yang penting bagi diri seseorang. Dari kompetensi yang inilah perusahaan jadi lebih mengetahui bagaimana seorang bertanggung jawab, menyelesaikan masalah, dan mentransfer informasi kepada orang lain terkait tugas yang diinstruksikan oleh atasannya. Pada intinya, kompetensi digunakan untuk merencanakan, membantu, dan mengembangkan perilaku dan kinerja seseorang. Tidak hanya itu, melalui kompetensi kerja seorang karyawanlah perusahaan dapat mengetahui kekuatan dan kelemahan pekerjanya, c.komitmen organisasi, komitmen pada setiap karyawan sangat penting karena dengan suatu komitmen seorang karyawan dapat menjadi lebih bertanggung jawab terhadap pekerjaannya dibanding dengan karyawan yang tidak mempunyai komitmen. Biasanya karyawan yang memiliki suatu komitmen, akan bekerja secara optimal sehingga dapat mencurahkan perhatian, pikiran, tenaga dan waktunya untuk pekerjaanya, sehingga apa yang sudah dikerjakannya sesuai dengan yang diharapkan oleh perusahaan, 2 . bagi akademisi, diharapkan penelitian ini dapat berguna bagi mahasiswa/i yang ingin meneliti dengan objek tersebut, diharapkan 
bagi penelitian berikutnya adapun saran dari saya, adanya objek yang dapat diteliti namun belum di teliti pada penelitian ini yaitu objek motivasi. Karena didalam suatu perusahaan objek motivasi cukup dapat berpengaruh terhadap kinerja karyawan. Maka dari itu diharapkan dapat menambahkan objek tersebut.

\section{Daftar Pustaka}

[1] Tangkilisan, H. N. S. (2005). Manajemen publik. Jakarta: Grasindo

[2] Mangkunegara, A. A. A. P. (2006). Evaluasi Kinerja SDM. Cetakan Kedua. Bandung: PT. Refika Aditama

[3] Hariandja, M. TE. (2002). Manajemen Sumber Daya Manusia. Jakarta: Grasindo

[4] Gorda, I. G. N. (2006). Manajemen Sumber Daya Manusia. Cetakan Ketiga. Denpasar: Astabrata Bali

[5] Safaria dan Saputra. (2009). Manajemen Emosi. Yogyakarta: Bumi Aksara

[6] Mondiani, T. (2012). Pengaruh Kepemimpinan Transformasional dan Kompensasi terhadap Kinerja Karyawan PT. PLN (Persero) UPJ Semarang. Administrasi Bisnis, 1

[7] Rahyuda, Ni Kadek Winie Kaori Intan Mahkota, Sintaasih, D. K. dan R. A. G. (2017). Pengaruh Kepemimpinan Transformasional dan Budaya Organisasi Terhadap Komitmen Organisasi dan Kinerja Karyawan pada PT. Sasjam Riri di Kabupaten Gianyar, 11, 39854014

[8] Ritawati, A. (2013). Pengaruh Kepemimpinan Transformasional Dan Budaya Organisasi Terhadap Kepuasan Kerja Dan Kinerja Karyawan PT . Jamsostek ( Persero ) Cabang Surabaya, $9(1)$

[9] Tucunan, Roy,Supartha, A. R. dan W. G. (2014). Pengaruh Kepemimpinan Transformasional Terhadap Motivasi dan Kinerja Karyawan (Sudi Kasus Pada PT. Pandawa), 9, 533-550

[10] Kharis, I. (2015). Pengaruh Gaya Kepemimpinan Transformasional Terhadap Kinerja Karyawan Dengan Motivasi Kerja Sebagai Variabel Intervening (Studi Pada Karyawan Bank JATIM cabang Malang), 3(1), 1-9

[11] Italiani, F. A. (2013). Pengaruh Gaya Kepemimpinan Transformasional Dan Transaksional Terhadap Kinerja Pegawai Departemen SDM PT. Semen Gresik (PERSERO) TBK, 6(031).

[12] Tintami Lila, Pradhanawati, Ari dan Susanto, H. (2012). Pengaruh Budaya Organisasi Dan Gaya Kepemimpinan Transformasional
Terhadap Kinerja Karyawan Melalui Displin Kerja Pada Karyawan Harian SKT Megawan IIPT. Djarum Kudus, 1-8.

[13] Atosokhi, A. (2014). Integritas Personal dan Kepemimpinan Etis. Humaniora, 5, 950-959.

[14] Salwa, Arfah, Away, Yuwaldi dan Tabrani, M. (2018). Pengaruh Komitmen, Integritas Dan Kompetensi Terhadap Kinerja Pegawai Serta Dampaknya Pada Kinerja Komisi Independen Pemilihan (KIP) Aceh, 2(1), 5867.

[15] Sujiyanto, S. (2017). Pengaruh Integritas Dan Loyalitas Pegawai Terhadap Kebijakan Pimpinan dan Dampaknya Terhadap Kinerja di Lingkungan Dinas Komunikasi dan Informatika Kota Batu, II.

[16] PascaBaisary, R. (2013). Pengaruh Integritas, Obyektivitas, Kerahasiaan, Kompetensi, dan Komitmen Terhadap Kinerja Auditor pada kantor perwakilan badan pengawasan keuangan dan pembangunan (BPKP) Provinsi Sulawesi Tengah. E-Journal Katalogis, 1, 124-135.

[17] Hendrawan, P. R. dan, \& Budiartha, I. K. (2018). Pengaruh Integritas , Independensi , dan Gaya Kepemimpinan Transformasional pada Kinerja Auditor Inspektorat Kota Denpasar, 24, 1359-1386.

[18] Boulter, N., Dalziel.M.dan Hill, J. (1996). People and Competencies.Bidlles.Ltd London.

[19] Dhermawan, Anak Agung Ngurah Bagus, Sudibya I Gde Adnyana dan Utama, I. W. M. (2012). Pengaruh Motivasi, Lingkungan Kerja, Kompetensi, dan Kompensasi Terhadap Kepuasan Kerja dan Kinerja Pegawai di Lingkungan Kantor Dinas Pekerjaan Umum Provinsi Bali., 6(2), 173184.

[20] Manik, S. dan, \& Syafrina, N. (2018). Pengaruh Kompetensi Terhadap Kinerja Dosen Sekolah Tinggi Ilmu Ekonomi Riau., 11(1), 1-6.

[21] Toly, A. A. (1999). Analisis Faktor-Faktor Yang Mempengaruhi Turnover Intentions pada Staf Kantor Akuntan Public. Akuntansi \& Keuangan, Universitas Kristen Petra,. Akuntansi \& Keuangan, Universitas Kristen Petra, 102-125.

[22] Pantja, Djati S dan Khusaini, M. (2003). Kajian Terhadap Kepuasan Kompensasi, Komitmen Organisasi, Dan Prestasi Kerja. Jurnal Manajemen \& Kewirausahaan, 5, 2441.

[23] Lovina, Hendriani, S. dan M. (2017). Pengaruh Kepemimpinan, Komitmen Organisasi dan Budaya Organisasi Terhadap Kinerja Pegawai Dinas Pendapatan Provinsi Riau., 5(2), 156-178 
Jurnal Sains, Teknologi dan Industri, Vol. 16, No. 2, Juni 2019, pp.132 - 141

ISSN 2407-0939 print/ISSN 2721-2041 online

[24] Handayani, W. (2008). Dampak Komitmen Organisasi, Self Efficiacy Terhadap Konflik Peran dan Kinerja Karyawati PT. HM SAMPOERNA Tbk. di Surabaya., 8(2), 70 78. 